\title{
Implementasi Pendekatan Remedial untuk Pengentasan Masalah Belajar
}

\author{
${ }^{1}$ Hamdanah, ${ }^{2}$ Abd. Muis Said, \\ ${ }^{1}$ IAIN Parepare, South Sulawesi, Indonesia \\ ${ }^{2}$ UIN Alauddin Makassar, South Sulawesi, Indonesia \\ Email: hamdanahsaid@gmail.com
}

\begin{abstract}
ABSTRAK
Implementasi pendekatan remedial untuk membantu peserta didik mencapai atau melampaui standar Ketuntasan Belajar Minimal (KBM) dalam pembelajaran menjadi sangat urgen sebagai upaya pengentasan masalah belajar yang kini masih banyak dialami oleh peserta didik. Penelitian ini bertujuan untuk mendeskripsikan bentuk implementasi pendekatan remedial, memperoleh gambaran yang jelas tentang dukungan guru Bimbingan dan Konseling terhadap pelaksanaan remedial serta faktor yang mempengaruhi remedial sehingga dapat mengentaskan masalah belajar. Pendekatan Remedial diduga kuat mampu mengentaskan masalah belajar peserta didik karena itu, riset ini berfungsi untuk mencari hal itu. Penelitian ini menggunakan pendekatan naturalistik kualitatif, dilaksanakan pada 3 SMK Negeri di Kota Parepare, dengan teknik pengumpulan data wawancara dan observasi. Teknik analisis data yang digunakan adalah analisis induktif. Setelah menginterviu dan mengobservasi di lapangan, penulis menemukan fakta bahwa: 1) bentuk implementasi pendekatan remedial mata pelajaran PAI pada SMKN di Parepare berupa pembelajaran remedial perorangan secara insidentil setelah tes formatif dan remedial kelompok setelah tes sumatif. 2) Dukungan guru Bimbingan dan Konseling terhadap implementasi pendekatan remedial bervariasi. Pada SMKN 1 Parepare dukungan berupa identifikasi dan diagnosis masalah belajar, layanan informasi bagi peserta didik yang harus mengikuti remedial, pemberian konseling perorangan terhadap peserta didik yang turun peringkatnya, dan pengawasan terhadap kedisiplinan peserta didik. Sedangkan pada SMKN lainnya, remedial menjadi tanggungjawab guru mata pelajaran, guru BK hanya menangani jika ada peserta didik yang bolos atau lebih dari tiga kali mangkir dalam pembelajaran. 3) Faktor yang mempengaruhi remedial sehingga dapat mengentaskan masalah belajar adalah antusiasme guru PAI dalam mengemban tugasnya, optimalisasi kegiatan ekstra kurikuler, bimbingan iman dan taqwa, dukungan kepala sekolah serta adanya inisiatif guru memberikan bimbingan belajar di luar jam pelajaran. Pendekatan remedial membantu mengentaskan masalah belajar dan meningkatkan mutu pembelajaran. Ini menunjukkan bahwa pendekatan remedial dapat menjadi solusi pengentasan masalah belajar peserta didik.
\end{abstract}

\section{Kata Kunci: Pendekatan Remedial, Pengentasan, Masalah belajar.}

\section{PENDAHULUAN}

Belajar merupakan bagian yang tidak terpisahkan dengan kehidupan manusia dan secara terus menerus menjadi proses yang alami, baik di lingkungan rumah tangga, sekolah, maupun di lingkungan masyarakat. Belajar merupakan sesuatu yang mutlak bagi setiap individu yang menjadi jalan bagi perkembangan potensinya menuju kedewasaan.

Muhyi Batubara (2004:114) menegaskan bahwa bila bangsa ini ingin menjadi bangsa yang maju dan modern, bangsa yang mempunyai peradaban yang tinggi, bangsa yang bermartabat dimata dunia internasional yang tidak dipandang sebelah mata, bangsa yang mampu bersaing dipasar global, pemerintah sebagai penyelenggara negara yang memiliki tanggungjawab besar dalam menata pendidikan sebagai bagian dari perencanaan sistem pembangunan nasional harus berani berinvestasi kepada sektor pendidikan.

Penyelenggaraan pendidikan dan pembelajaran di Sekolah membutuhkan upaya optimal dari seluruh penanggungjawab penyelenggaraan pendidikan terutama para guru. Dalam mengemban tugas mulia, guru senantiasa menghadapi perubahan dan pengembangan di bidang pendidikan termasuk perubahan dan pengembangan pendekatan dan metode pembelajaran. Hal 
ini sejalan dengan apa yang dikemukakan oleh Pupuh Pathurrohman (2014:91) bahwa "Pendidikan adalah perubahan, karena itu pelaksanaan pendidikan setiap waktu mengandung masalah untuk diselesaikan".

Mata pelajaran Pendidikan Agama Islam (PAI) merupakan salah satu mata pelajaran yang diajarkan di Sekolah Menengah Kejuruan seperti halnya pada sekolah lainnya, yang lebih mengarahkan peserta didik kepada kehidupan yang baik melalui ajaran agama Islam, namun kadang-kadang peserta didik mengalami kesulitan dalam pembelajaran atau jenuh saat pembelajaran berlangsung. Bila hal demikian dibiarkan berlarut, maka akan berdampak negative pada mutu pembelajaran PAI.

Peserta didik mengikuti pendidikan formal dengan harapan agar dapat mengikuti proses pendidikan dan pembelajaran dengan baik serta dapat mencapai perkembangan optimal. Namun, tidak selamanya demikian. Ada berbagai masalah yang mereka hadapi baik yang bersumber dari dalam diri maupun dari luar diri mereka. Masalah yang dimaksud dapat disebabkan karena kemampuan dasar yang rendah, ketidak mampuan menyelesaikan tugas, persaingan dengan teman, guru yang kurang ramah, motivasi belajar yang rendah, kurangnya dukungan orang tua, dan lain-lain. Masalah-masalah tersebut tidak selalu dapat diselesaikan dalam proses pembelajaran di kelas, melainkan memerlukan pelayanan secara khusus oleh guru di luar situasi proses pembelajaran. Pelayanan khusus ini membutuhkan kerjasama antara guru mata pelajaran dengan guru lembaga Bimbingan dan Konseling. S. Nasution (2011: vi) mengemukakan bahwa guru cenderung menerima bahwa dalam tiap kelas terdapat sekitar $25 \%$ anak yang pandai yang memperoleh angka yang baik, 50\% anak-anak yang sedang yang diberi angka 6 dan 25\% yang mendapat angka kurang. Lebih lanjut beliau mengemukakan bahwa mastery learning memberi jalan agar lebih dari $80 \%$ anak-anak mendapat angka tertinggi tanpa menghiraukan kurva normal. Dengan demikian pendekatan remedial sebagai salah satu pendekatan bimbingan dan konseling, menjadi urgen untuk dilakukan.

Pelaksanaan remedial di SMK merupakan salah satu kebutuhan mendasar mengingat bahwa dalam proses pendidikan dan pembelajaran tidak semua peserta didik terhindar dari kesulitan atau masalah,termasuk masalah belajar yang mereka tidak mampu menyelesaikannya sendiri. Hal ini disadari oleh setiap guru bahwa dalam proses pembelajaran selalu ada peserta didik yang mengalami kesulitan belajar sehingga peserta didik yang bersangkutan tidak mampumencapai ketuntasan belajar. Namun, kesadaran tersebut belum sepenuhnyaditindaklanjuti dengan baik oleh para guru untuk mengupayakan solusinya.

Sasaran akhir pelaksanaan remedial adalah sama dengan pembelajaran pada umumnya, yaitu membantu peserta didik dalam batas-batas normalitas tertentu agar dapat mengembangkan diri seoptimal mungkin sehingga mencapai tingkat penguasaan tertentu, sekurang-kurangnya sesuai dengan batas kriteria keberhasilan yang dapat diterima (minimum acceptable performance). Mengingat secara empirik sasaran tingkat strategis itu tidak selamanya dapat dicapai dengan pendekatan sistem pembelajaran konvensional, maka perlu dicari upaya pendeketan strategis lainnya. Pembelajaran remedial, bertujuan agar peserta didik dapat mencapai tujuan pembelajaran yang telah ditetapkan, sekurang-kurangnya sesuai dengan derajat ketuntasan minimum.

Atas dasar pemikiran awal dan fenomena di lapangan, peneliti tertarik untuk mengangkat permasalahan penelitian tentang implementasi pendekatan remedial dalam mengentaskan kesulitan belajar PAI peserta didik sehingga diharapkan dapat menjadi bahan informasi dalam rangka pengambilan kebijakan dalam upayapeningkatkan mutu pelaksanaan remedial dan 
pengentasan masalah belajar PAI peserta didik di Sekolah dan lebih khusus pada SMK Negeri di Kota Parepare. Penelitian ini bertujuan untuk mendeskripsikan bentuk pelaksanaan remedial mata pelajaran PAI pada SMK Negeri di Kota Parepare, memperoleh gambaran yang jelas tentang dukungan guru Bimbingan dan Konseling terhadap pelaksanaan program remedial mata pelajaran PAI, mengetahui faktor-faktor yang mempengaruhi remedial sehingga dapat mengentaskan masalah belajar PAI peserta didik SMK Negeri di Kota Parepare.

\section{Kajian Teori}

1. Hakikat dan Tujuan Pendekatan Remedial

Bimbingan dan konseling merupakan salah satu bidang utama dalam proses pendidikan di Sekolah. Hal ini sejalan dengan pernyataan Nana Syaodih Sukmadinata (2007:1) bahwa keseluruhan proses pendidikan terutama pendidikan di sekolah meliputi tiga bidang utama, yaitu bidang: kurikulum dan pembelajaran, manajemen pendidikan, dan bimbingan dan konseling. Bimbingan dan Konseling merupakan bidang layanan kepada peserta didik (student services) yang membantu mereka dalam rangka mencapai perkembangan optimal sesuai dengan predisposisi atau potensi dasar yang dimilikinya.

Pendekatan remedial umumnya dilakukan melalui pembelajaran remedial. Pendekatan remedial merupakan salah satu jenis pendekatan dalam bimbingan dan konseling di Sekolah. Amin Budiamin dan Setiawati (2009:27) mengemukakan bahwa dalam pendekatan ini, guru memfokuskan bantuannya pada upaya menyembuhkan atau memperbaiki kelemahan-kelemahan peserta didik yang tampak.

Abin Syamsuddin Makmun dalam Amin Budiamin (2009:95) mendefinisikan pembelajaran remedial sebaga upaya guru untuk menciptakan suatu situasi yang memungkinkan peserta didik atau kelompok peserta didik tertentu lebih mampu mengembangkan dirinya seoptimal mungkin sehingga dapat memenuhi kriteria keberhasilan minimal yang diharapkan, dengan melalui suatu proses interaksi yang terencana, terorganisir, terarah, terkoordinasi, terkontrol dengan lebih memperhatikan taraf kesesuaiannya terhadap keragaman kondisi objektif individu dan atau kelompok peserta didik yang bersangkutan serta daya dukung sarana dan lingkungannya.

Dari beberapa pengertian di atas dapat dipahami bahwa pembelajaran remedial merupakan suatu proses layanan pembelajaran yang bersifat korektif, yang bertujuan untuk memperbaiki kelemahan, kekurangan serta kesalahan peserta didik berdasarkan hasil evaluasi dan diagnosis yang telah diberikan secara kontinyu dalam proses pembelajaran. Pembelajaran remedial merupakan pemberian perlakuan khusus kepada peserta didik yang mengalami hambatan atau masalah dalam kegiatan belajarnya dalam rangka memperbaiki prestasi belajarnya sehingga mencapai hasil belajar sesuai kriteria ketuntasan belajar yang telah ditetapkan.

Pembelajaran remedial merupakan salah satu kegiatan utama dari layanan bimbingan belajar serta merupakan rangkaian daripada diagnosis kesulitan belajar peserta didik "Strategi dan teknik pembelajaran dapat dilakukan secara preventif, kuratif, dan pengembangan".(Amin Budiamin, 2009:95). Layanan pengajaran remedial bersifat preventif jika diberikan kepada peserta didik tertentu yang diprediksi akan mengalami hambatan dalam proses dan capaian pembelajaran yang harus dipenuhinya. Dikatakan bersifat kuratif jika layanan remedial diberikan kepada peserta didik yang memiliki masalah setelah proses pembelajaran utama dilaksanakan. 
Selanjutnya, pendekatan remedial bersifat pengembangan jika layanan tersebut merupakan tindak lanjut dari upaya diagnostik yang dilakukan selama berlangsungnya proses pembelajaran.

2. Bentuk-Bentuk Implementasi Pendekatan Remedial

Implementasi pendekatan remedial di sekolah dapat dilekukan dengan berbagai bentuk.Menurut Nana Syaodih Sukmadinata (2007:286) "layanan remedial atau korektif dapat dilakukan melalui konseling individual atau kelompok, juga melalui kegiatan-kegiatan kelompok". Layanan dari guru pembimbing atau guru mata pelajaran lebih difokuskan pada peserta didik yang memiliki masalah belajar pada mata pelajaran tertentu yang disesuaikan dengan karakteristik peserta didik.

Cara lain yang dapat dilakukan adalah melalui pengajaran modul. Menurut S. Nasutiaon (2011:207) pengajaran modul dengan sengaja memberi kesempatan untuk pengajaran remedial yakni memperbaiki kelemahan, kesalahan, aatau kekurangan peserta didik yang segera dapat ditemukan sendiri oleh peserta didik berdasarkan evaluasi yang diberikan secara kontunu. Lebih lanjut beliau menjelaskan bahwa peserta didik tidak perlu mengulangi pelajaran secara keseluruhan akan tetapi hanya yang berkenaan dengan kekurangan itu.

Pendekatan pembelajaran remedial merupakan bentuk pembelajaran yang tidak sekedarmengulang terhadap bahan-bahan pelajaran pokok yang belum dapat dikuasai oleh peserta didik tetapi juga merupakan studi kasus bagi guru untuk mengetahui dan menangani peserta didik yangmengalami masalah belajar. Pembelajaran remedial dapat diselenggarakan denganberbagai bentuk kegiatan antara lain:

1) Memberikan tambahan penjelasan atau contoh. Peserta didik kadang-kadang mengalami kesulitan memahami penyampaian materiyang disajikan hanya sekali. Pemberian tambahan ilustrasi, contoh akan membantupembentukan konsep pada diri peserta didik .

2) Menggunakan strategi, metode, dan atau taktik pembelajaran yangberbeda dengan sebelumnya. Penggunaan alternatif berbagai strategi, metode, dan taktik pembelajaranakan memungkinkan peserta didik dapat mengatasi masalah pembelajaran yang dihadapi.

3) Mengkaji ulang pembelajaran yang lalu. Penerapan prinsip pengulangan akanmembantu peserta didik menangkap pesan-pesan pembelajaran. Pengulangan dapat dilakukandengan menggunakan metode dan media yang sama atau metode dan media yangberbeda.

4) Menggunakan multimedia. Penggunaan multimediadapat menarik minat, motivasi dan perhatian peserta didik. Semakin tinggi minat, motivasi dan perhatian maka hasil belajar akan menjadi lebihbaik dari sebelumnya. Pembelajaran remedial berguna untuk mengadakan pembetulan terhadapkesalahan atau kesulitan yang dialami peserta didik. Dengan diberikannya Pembelajaranremedial bagi peserta didik yang belum mencapai tingkat ketuntasan belajar, maka peserta didiktersebut mempunyai peluang besar untuk mencapai tingkatpenguasaan dan ketuntasan dalam belajar.

Pelaksanaan pembelajaran remedial dapat pula dilaksanakan dengan cara penyederhanaan materi dan penggunaan bahasa, pemberian latihan khusus, pemanfaatan tutor sebaya serta penyederhanaan bentuk tes atau pertanyaan sesuai dengan karakteristik peserta didik. Hal ini didasarkan pada hasil tes formatif yang merupakan alat untuk mengungkapkan dimana letak kesulitan yang dialami peserta didik. Dengan demikian tes formatif merupakan alat untuk mendiagnosis masalah belajar peserta didik berupa kelemahan dan kekurangan yang dialaminya untuk kemudian dijadikan dasar pemberian perlakuan perbaikan atau remedial.

\section{Masalah Belajar dan Faktor Penyebabnya}


Masalah belajar merupakan suatu kondisi tertentu yang dialami oleh peserta didik dan menghambat kelancaran proses belajarnya. Kondisi tertentu itu dapat berkenaan dengan keadaan dirinya yaitu berupa kelemahan-kelemahan yang dimilikinya dan dapat juga berkenaan dengan lingkungan yang tidak menguntungkan bagi dirinya. Masalah-masalah belajar tidak hanya dialami oleh peserta didik yang lambat dalam belajarnya, akan tetapi juga dapat menimpa peserta didik yang pandai atau cerdas (Amin Budiamin dan Setiawati, 2009:113).

Tidak semua peserta didik yang mengalami masalah belajar dapat mengatasi sendiri masalahnya. Dengan demikian perlu mendapatkan bantuan agar masalah yang dialami peserta didik yang bersangkutan tidak berlarut-larut, yang nantinya dapat mempengaruhi proses perkembangannya. Dengan pemberian layanan bimbingan dan konseling melalui pendekatan remedial dimungkinkan masalah belajar peserta didik dapat terentaskan. Baik berupa kelambatan dalam belajar maupun perolehan prestasi rendah (under achiever).

Perbedaan karakteristik dan predisposisi yang dimiliki peserta didik dapat berakibat pada adanya berbagai gangguan, hambatan, ancaman, dan kesulitan yang dialami dalam proses belajarnya. Alan D Ross (1974:98) mengemukakan bahwa "A learning difficully refresente a discrepancy between a child's estimated academic potencial and actual level of academic performance". Ini menggambarkan bahwa peserta didik digolongkan mengalami kesulitan belajar, apabila peserta didik tersebut tidak mencapai tingkat kualifikasi hasil belajar tertentu dalam batas waktu tertentu, misalnya, mengulang satu atau beberapa mata pelajaran, tinggal kelas atau tidak lulus ujian.

Moh. Surya dalam Hellen A mengemukakan bahwa ada beberapa ciri tingkah laku yang merupakan manifestasi dari gejala kesulitan belajar, antara lain:

a. Menunjukkan hasil belajar yang rendah (di bawah rata - rata nilai yang dicapai oleh kelompok kelas)

b. Hasil yang dicapai tidak seimbang dengan usaha yang dilakukan. Mungkin murid yang selalu berusaha dengan giat tapi nilai yang dicapai selalu rendah.

c. Lambat dalam melakukan tugas - tugas kegiatan belajar, ia selalu tertinggal dari kawan kawannya dalam menyelesaikan tugas sesuai dengan waktu yang tersedia.

d. Menunjukkan tingkah laku yang berkelainan, seperti membolos, datang terlambat, tidak mengerjakan pekerjaan rumah, mengganggu di dalam dan di luar kelas, tidak mau mencatat pelajaran dsb.

e. Menunjukkan sikap - sikap yang kurang wajar, seperti acuh tak acuh, menentang, berpura pura, dusta dsb.

f. Menunjukkan gejala emosional yang kurang wajar, seperti pemurung, mudah tersinggung, pemarah, tidak atau kurang gembira dalam menghadapi nilai rendah tidak menunjukkan sedih atau menyesal, dsb (Hellen A., 2002:129).

Gejala kesulitan belajar seperti yang dikemukakan di atas amat penting diamati dan dicermati oleh setiap guru mata pelajaran PAI dan guru BK. Guru dapat mengidentifikasi peserta didik yang mengalami masalah belajar PAI dengan mengamati gejala-gejala yang tampak pada diri peserta didik dalam proses pembelajaran.

\section{Metode Penelitian}

Penelitian ini merupakan penelitian kualitatif dalam bentuk penelitian lapangan (field research). Untuk mengetahui kondisi yang objektif dan mendalam tentang fokus penelitian ini 
dilakukan dengan menggunakan pendekatan kualitatif. Hal ini sesuai dengan pendapat Creswell dalam Sugiyono (2012:13) yang menyatakan bahwa: Qualitative research is a means for exploring and understanding the meaning individuals or groups ascribe to a social or human problem. Proses dalam hal ini merupakan kegiatan penyelidikan dengan fokus pada pengentasan kesulitan belajar PAI peserta didik melalui implementasi pendekatan remedial.

Penelitian ini menggunakan pendekatan naturalistik. Data dikumpul apa adanya, dan tidak dimanipulasi. Pengumpulan data dilakukan sendiri oleh peneliti dengan mendatangi sumbernya secara langsung. Sumber data dalam penelitian ini, yakni guru PAI, guru BK dan beberapa orang peserta didik yang telah mengikuti remedial sebagai sumber data primer. Sedangkan Kepala Sekolah, Pengawas PAI dan dokumen yang terkait dan relevan dengan focus penelitian merupakan sumber data sekunder.

Teknik pengumpulkan data yang digunakan dalam penelitian ini sebagai berikut:

a. Wawancara Mendalam

Wawancara mendalam dilakukan terhadap informan kunci yang ditetapkan yang sesuai dengan fokus penelitian yaitu ; (1) Kepala Sekolah (2) Guru BK (3) guru bidang studi PAI (4) dan beberapa orang peserta didik. Wawancara mendalam dilakukan melalui percakapan dialogis (interaktif), pertanyaan langsung secara terbuka (openendedquestions), dan tematik untuk memperoleh makna yang terungkap secara mendasar. Tema pokok wawancara yaitu; (1) bentukbentuk pelaksanaan remedial, (2) langkah-langkah remedial, (3) dukungan guru BK terhadap guru PAI, (4) kesulitan belajar PAI peserta didik, dan (5) optimalisasi pelaksanaan remedial dalam mengentaskan masalah belajar PAI peserta didik.

b. Dokumentasi

Sumber data utama penelitian ini adalah dokumen yang terkait dan relevan dengan pelaksanaan remedial. Dokumen yang relevan dengan focus penelitian, seperti; himpunan data, foto, catatan atau tulisan-tulisan yang ada kaitannya dengan fokus penelitian, program remedial, pedoman pendidikan, dan dokumen lain yang sesuai dengan fokus penelitian.

c. Observasi

Teknik observasi dalam penelitian ini digunakan untuk memeriksa dan melengkapi rekaman hasil wawancara yang dilakukan dengan informan.Langkah ini dilakukan karena ada kemungkinan bahwa informasi yang diperoleh belum menyeluruh (holistik dan integratif), belum menggambarkan konteks dan setting penelitian atau terjadi kemandegan informasi.

Teknis analisis data yang dilakukan meliputi 4 jenis analisis, yaitu: (1) analisis teoritik, (2) analisis hasil wawancara, (3) analisis hasil observasi dan (4) analisis dokumen.

Proses menganalisis data dalam penelitian ini juga melalui dua tahapan. Pertama, analisis kasus data lapangan yang dimulai pada saat pengumpulan data, terdiri dari; 1) checking, 2) organizing, dan 3) coding.Kedua, analisis data sesudah terkumpul secara keseluruhan yang meliputi; 1) meaning, 2) interpretative, dan 3) conclution.Agar diperoleh temuan-temuan hasil penelitian dengan interpretasi yang absah dari data yang berhasil dikumpulkan, dilakukan pengecekan atas keabsahan temuan dan interpretasi data sehingga diperoleh nilai-nilai kebenaran.Untuk keperluan itu dilakukan uji kredibilitas, dependabilitas, dan konfirmabilitas data.

\section{HASIL PENELITIAN DAN PEMBAHASAN}

\section{Hasil Penelitian}

Hasil penelitian sebagaimana temuan di lapangan dikemukakan pada bagian ini yakni temuan fakta terhadap bentuk-bentukimplementasi pendekatan remedial dalam 
pembelajaranPAI, dukungan guru BK terhadap pelaksanaan pendekatan remedial, kemudian dijelaskan pula beberapa hal yang mendukung sehingga implementasi remedial dapat mengentaskan masalah belajar PAI peserta didik pada SMKN di Kota Parepare.

\section{a. Bentuk-bentuk Implementasi Pendekatan Remedial pada Mata Pelajaran PAI}

Pendekatan remedial merupakan salah satu alternatif pendekatan yang diterapkan pada lembaga pendidikan formal termasuk pada SMKN di Kota Parepare untuk mewujudkan ketuntasan pembelajaran. Dalam pelaksanaan pembelajaran tidak semua peserta didik mencapai ketuntasan dalam belajar, artinya ada peserta didik yang tidak mencapai standar kompetensi yang telah ditetapkan dalama p[elaksanaan pembelajaran sehingga perlu mengikuti pembelajaran remedial.

Penelitan ini merupakan penelitian kualitatif sehingga pengumpulan data untuk memperoleh gambaran mengenai bentuk-bentuk pelaksanaan pendekatan remedial pada Mata Pelajaran PAI pada SMKN di Kota Parepare dengan menggunakan teknik wawancara mendalam. Hal ini dilakukan oleh peneliti terhadap informan yang merupakan sumber data primer dan sekunder yakni beberapa orang guru PAI, kepala sekolah, pengawas PAI SMK, guru BK, dan peserta didik yang dipandang dapat mewakili sebagai informan kunci (key informan). Di samping wawancara mendalan, juga dilakukan observasi dan penelusuran dokumen yang terkait dengan penelitian.Pelaksanaan penelitian ini secara bertahap pada 3 SMKN yang menjadi objek penelitian pada bulan Juli s.d. Oktober 2017.

Hal lain yang dicermati kaitannya dengan penerapan pendekatan remedial adalah penilaian. Penilaian merupakan elemen penting dalam proses pembelajaran yang dilakukan oleh guru. Tanpa penilaian, semua pihak sulit mengontrol peningkatan pengetahuan, pemahaman, sikap, dan ketrampilan peserta didik dan sulit menentukann ketuntasan pembelajaran seperti dikatakan dalam pernyataan berikut.

Kita ketahui bahwa penilaian itu merupakan kunci utama dalam mengukur hasil proses belajar peserta didik. Salah satu penilaian penting di sekolah ini adalah penilaian harian, kemudian penilaian ujian tengah semester, dan ujian akhir semester. Terus terang yang kami lakukan ibu, kalau berdasarkan betul hasil penilaian itu, banyak sekali peserta didik yang tidak bisa lulus dalam ujian akhir. Jadi otomatis kami berusaha betul agar semuanya memenuhi standar dan semuanya bisa mencapai standar KKM dan semuanya naik kelas.Apalagi ada harapan bahwa sedapat mungkin jangan ada peserta didik yang tinggal kelas. (Hj. Nurhayati)

Berdasarkan hasil wawancara terhadap pelaksanaan penilaian pembelajaran yang berlangsung pada SMKN di Kota Parepare bahwa penilaian terdiri atas tiga bagian, penilaian harian berupa latihan dan tugas, penilaian tengah semester, dan penilaian akhir semester. Jadi, sistem pembelajaran masih terpusat pada guru, sedangkan penilaian berorientase pada proses dan dan hasil. Artinya, dapat dikatakan bahwa kecenderungan terjadi perubahan proses pembelajaran dari pendekatan yang berpusat pada guru menuju yang berpusat pada peserta didik berada pada tahap transisi. Dengan demikian, perubahan paradigma pembelajaran nampaknya telah dimulai dari proses penilaian yang dilakukan dalam ruang kelas menuju pada rancangan pembelajaran yang berujung pada pelaksanaan pembelajaran khususnya dalam hubungannya dengan penerapan aktivitas pembelajaran dan sesuai dengan tuntutan penerapak kurikulum 2013 (K13). 


\section{b. Bentuk Dukungan Guru Bimbingan dan Konseling terhadap Implementasi Program Remedial pada Mata Pelajaran PAI}

Penerapan aktivitas pendidikan dan pembelajaran sangat penting untuk dilakukan terutama pada lembaga pendidikan formal. Aktivitas tersebut sangat berguna utamanya dalam meningkatkan pengetahuan, pemahaman, sikap, ketrampilan, motivasi, minat peserta didik dan membuat mereka menjadi lebih aktif, kreatif serta meningkatkan kemandirian dalam rangka pengembangan diri secara optimal. Namun dalam proses pendidikan dan pembelajaran, peserta didik kadang dihadapkan pada masalah atau hambatan yang tidak dapat dipecahkan sendiri tanpa bantuan orang lain. Dalam kondiisi seperti ini, keberadaan layanan bimbingan dan konseling menjadi sangat urgen, terutama jika guru mata pelajaran tidak dapat membantu mengentaskan masalah tersebut.

Penerapan asas keterpaduan sebagai salah satu asas dalam layanan bimbingan dan konseling menghendaki adanya kerjasama antara guru mata pelajaran dengan guru BK dalam membantu peserta didik yang mengalami kesulitan belajar.Jika guru mata pelajaran tidak berhasil membantu peserta didik mengentaskan masalah yang dihadapinya, maka guru mata pelajaran dapat mengalihtangankan masalah tersebut pada guru BK.

Berdasarkan hasil observasi peneliti di lapangan, tampak bahwa semua SMK Negeri di Kota Parepare mempunyai lembaga Bimbingan dan Konseling (BK). Guru BK yang bertugas pada SMKN di Kota Parepare seluruhnya berstatus Pegawai Negeri Sipil dan berlatarbelakang pendidikan program studi BK. Jumlah guru BK pada SMKN 1 sebanyak 3 orang, SMKN 2 sebanyak 6 orang, dan pada SMKN 3 sebanyak 2 orang. Masing-masing memiliki ruang khusus untuk pemberian layanan BK.

Program Pemberian layanan yang dilaksanakan pada tiga SMKN berpariasi. Jika merujuk pada rambu-rambu penyelenggaraan BK maka dapat terlihat bahwa implementasinya belum sepenuhnya sesuai dengan tuntutan yang dikehendaki dalam rambu-rambu penyelenggaraan BK itu sendiri. H. Muhammad Tang (guru PAI SMKN 3) mengemukakan bahwa penerapan aktivitas pendidikan dan pembelajaran sangat penting untuk dilakukan agar peserta didik dapat berkembang seoptimal mungkin menuju kedewasaan. Namun dalam proses tersebut kadang-kadang ada peserta didik yang suka bandel, suka bolos, malas mengerjakan tugas, dan berbuat nakal. Anak yang demikian saya tangani sendiri masalahnya, bahkan ada yang saya beri hukuman lalu saya nasihati kembali tanpa meminta bantuan guru BK.

Sejalan dengan apa yang dikemukakan oleh H. Muhammad Tang di atas, Hj. Rahmatia mengemukakan pula bahwa hampir semua masalah pembelajaran PAI di sekolah ini ditangani sendiri oleh guru PAI, kecuali jika ada masalah kenakalan barulah dialihtangankan kepada guru BK. Dukungan guru BK dalam kaitannya dengan peningkatan proses dan hasil pembelajaran PAI maupun remedial bisa dikatakan tidak ada. Semuanya menjadi tanggungjawab guru PAI. Ungkapan ini dibenarkan oleh Drs. Supardi B. (guru BK SMKN 2) bahwa kami tidak pernah memberikan layanan kepada peserta didik yang berkaitan dengan proses dan hasil belajar PAI. Masalah proses dan hasil belajar sepenuhnya menjadi tanggungjawab guru mata pelajaran termasuk PAI. BK hanya menangani masalah jika ada alih tangan dari guru mata pelajaran sedangkan guru PAI tidak pernah mengalihtangankan masalah peserta didiknya kepada guru BK. Lebih lanjut dikatakan bahwa jika ada peserta 
didik yang tidak mengikuti pelajaran sebanyak tiga kali maka barulah kami panggil orang tua yang bersangkutan ke sekolah membicarakan solusinya.

Berdasarkan hasil wawancara tentang dukungan guru BK terhadap pelaksanaan pembelajaran remedial sebagai solusi pencapaian ketuntasan pembelajaran PAI di atas dapat dipahami bahwa apa yang dilakukan pada SMKN 2 dan SMKN 3 berkenaan dengan pelaksanaan pendidikan dan pembelajaran PAI di sekolah belum sepenuhnya menunjukkan keterpaduan antara layanan guru PAI dan layanan guru BK dalam rangka mengoptimalkan perkembangan peserta didik. Perkembangan peserta didik pada mata pelajaran PAI sepenuhnya menjadi tanggungjawab guru PAI.Fungsi BK yang berjalan pada kedua SMKN tersebut dominan pada fungsi kuratif atau fungsi pengentasan masalah ketidakdisiplinan peserta didik jika ada alihtangan dari guru mata pelajaran.Namun secara khusus pada SMKN 1 Parepare telah terjalin hubungan dan kerjasama antara guru mata pelajaran PAI dengan guru BK dalam rangka mengoptimalkan perkembangan peserta didik termasuk dalam pengentasan masalah belajar peserta didik.

Dukungan guru BK pada SMKN 1 Parepare terhadap pengentasan masalah belajar peserta didik berdasarkan observasi dan penelusuran dokumen pada ruang kerja guru BK, ditemukan bahwa layanan yang diberikan telah sesuai dengan tuntutan yang dikehendaki oleh BK itu sendiri dengan menerapkan Pola 17 plus, yang dilengkapi dengan dokumen aplikasi instrumenasi BK serta himpunan data yang cukup lengkap.

Berdasarkan pengamatan dan wawancara di lapangan, terdapat pula beberapa dukungan guru BK terhadap pengentasan masalah belajar peserta didik yang diterapkan di sekolah.Secara umum dukungan tersebut dapat dibagi ke dalam dua bagian utama yakni aktivitas di dalam dan aktivitas di luar ruang kelas.Pertama, aktivitas di dalam ruang kelas seperti dikatakan sebagai berikut.

Secara tegas dikatakan bahwa aktivitas yang banyak digunakan adalah aktivitas pembelajaran yang berlangsung di dalam ruangan kelas yang merupakan aktivitas rutinitas informan dalam melaksanakan pembelajaran seperti dalam pernyataan di bawah ini.

Pada umumnya kegiatan yang saya berikan yang umum saja seperti kegiatan dalam ruangan, mengamati, menulis, membaca, menghafal, mengerjakan latihan soal-soal. Saya tidak banyak melibatkan peserta didik untuk melakukan aktivitas di luar ruangan mengingat keterbatasan waktu sehingga membuat kita betul-betul fokus pada kegiatan menerangkan materi pembelajaran, menghafal ayat dan hadis serta mengerjakan latihan soal-soal. Jika kebetulan saya tidak hadir melaksanakan tugas di kelas maka guru BK mengisi kelas tersebut dengan memberikan layanan khusus BK. (Hj. Harwiyani, guru PAI SMKN 1).

Berdasarkan hasil observasi ditemukan bahwa jika ada guru mata pelajaran yang tidak sempat menjalankan tugasnya pada jam pelajaran tertentu maka guru BK mengisi jam pelajaran yang kosong tersebut dengan memberikan layanan informasi, bimbingan karier, dan bimbingan belajar dan layanan BK lainnya, bukan mengambil alih tugas mengajarkan mata pelajaran guru yang digantikan. 
Kedua, aktivitas guru BK yang berlangsung di luar ruangan yang mencakup pengawasan terhadap ketidakdisiplinan peserta didik dalam mentaati tata tertib sekolah dan kegiatan ekstra kurikuler keagamaan.

Jika ada peserta didik yang bolos pada saat pembelajaran sedang berlangsung maka kami guru BK memanggil mereka lalu memberikan layanan konseling.Jika sudah 3 kali seorang peserta didik tidak hadir di sekolah atau absen tiga kali maka kami memanggil orangtua peserta didik yang bersangkutan ke sekolah untuk menyepakati solusi dari permasalahan tersebut. (Supardi, guru BK SMKN 2 Parepare)

Berdasarkan pernyataan dari hasil wawancara peneliti dengan informan tersebut di atas, maka dapat dikatakan bahwa dukungan guru BK terhadap pembelajaran PAI berupa kerjasama dalam hal: 1) Memberikan layanan konseling bagi peserta didik yang sering tidak hadir mengikuti proses pembelajaran dan yang turun prestasi belajarnya ,2) Mendiagnosis kesulitan belajar peserta didik, dan 3) Memberikan layanan informasi bagi peserta didik yang harus mengikuti remedial. Dukungan diberikan baik di dalam maupun di luar ruangan memberikan kontribusi dalam mengentaskan masalah belajar peserta didik. Dukungan dan kerjasama yang baik antara guru PAI dan guru BK merupakan cara yang baik dalam mengentaskan masalah belajar peserta didik.

Persoalan yang dihadapi Guru PAI dalam Pembelajaran pembelajaran dapat dibagi ke dalam kesulitan internal dan kesulitan eksternal. Kesulitan internal merujuk pada kemampuan berinovasi, dan keterampilan guru PAI dalam menggunakan teknologi informasi dan komunikasi dalam melaksanakan pembelajaran.Sedangkan, kesulitan eksternal terkait dengan rasio guru dan peserta didik dan sumber belajar termasuk saranan dan prasaranan pendukung.

Kesulitan internal adalah segala bentuk kesulitan yang berkaitan dengan kemampuan guru PAI dalam melaksanakan pembelajaran.Hasil observasi menunjukkan bahwa belum semua guru PAI luput dari kelemahan dalam kaitannya dengan menggunakan media, metode, dan strategi pembelajaran termasuk berbagai aktivitas yang melingkupinya.Solusi yang mereka lakukan adalah mendiskusikan dan mengatasi masalah tersebut pada kegiatan Musyawarah Guru Mata Pelajaran (MGMP) yang diselenggarakan setiap bulan.

Kesulitan eksternal terkait dengan rasio guru dan peserta didik dan sumber belajar termasuk saranan dan prasaranan pendukung. Disamping itu beban yang cukup berat dan mulia sekaligus sebagai bukti kinerja guru PAI dapat dilihat dengan adanya 3 orang guru PAI diberi kepercayaan sebagai Wakil Kepala Sekolah yakni satu orang pada SMKN 1 dan dua orang pada SMKN 3 Parepare.

Kegiatan MGMP guru SMKN se Kota Parepare dilaksanakan satu kali setiap bulan yakni mengadakan pertemuan untuk membahas berbagai masalah tugas dan tanggungjawab guru PAI di Sekolah dan mendapat arahan serta bimbingan dari Pengawas PAI.Melalui MGMP ini kami menemukan solusi setiap problem yang terkait dengan upaya peningkatan kinerja kami dalam mengemban tugas. Dengan ditemukannya solusi bagi setiap permasalahan yang ada maka optimalisasi layanan pembelajaran kepada peserta didik dapat terlaksanan sebagaimana yangbdiharapkan dalam rangka mengoptimalkan capaian pendidikan dan pembelajaran. 


\section{c.Faktor-faktor yang Mempengaruhi Remedial sehingga Dapat Mengentaskan Masalah Belajar PAI Peserta Didik}

Pendekatan remedial merupakan salah satu jenis pendekatan dalam bimbingan dan konseling di Sekolah yang umumnya dilaksanakan dalam bentuk pembelajaran remedial. Pelaksanaannya difokuskan pada pemberian bantuan kepada peserta didik dalam upaya menyembuhkan atau memperbaiki kelemahan-kelemahan peserta didik yang tampak sehingga peserta didik terhindar dari terjadinya krisis yang mungkin terjadi.

Berdasarkan pada observasi di lapangan tampak bahwa masalah belajar PAI yang dialami peserta didik dominan berkaitan dengan kemampuan membaca dan menulis ayat alQuran dan hadis serta pengamalan ibadah. Masalah tersebut sebagian besar pula bersifat psikopedagogis, merupakan sifat kesulitan belajar yang bersumber dari kondisi kejiwaan akibat pengaruh cara mengajar guru yang tidak bias mengakomodasi setiap karakter peserta didik. Masalah lain yang dialami peserta didik adalah kurangnya motivasi belajar PAI, lambat dalam memahami pelajaran, kebiasaan buruk dalam belajar PAI, dan faktor internal psikologis.

Pendekatan remedial ini disamping berfungsikuratifjuga dapat berfungsi developmental, yakni memperbaiki dan mengatasi kelemahan-kelemahan atau kekurangan-kekurangan yang terjadi pada diri peserta didik yang dapat menghambat perkembangannya bahkan dapat menjadi sebab tinggal kelas, tidak lulus ujian akhir atau drop out serta mengembangkan potensi peserta didik yang belum optimal perkembangannya.

Berhasil tidaknya pendekatan ini dalam mengentaskan masalah belajar peserta didik dipengaruhi oleh beberapa faktor. Menurut Clark dalam Hallen sebagaimana yang telah dikemukakan pada bab terdahulu bahwa "hasil belajar siswa di sekolah $70 \%$ dipengaruhi oleh kemampuan siswa dan 30\% dipengaruhi oleh lingkungan. Dengan demikian dapat penulis simpulkan bahwa keberadaab faktor pendukung dalam implementasi pendekatan remedial PAI sangat diperlukan sebagai strategi sebab tanpa adanya faktor pendukung implementasi remedial tidak dapat berhasil mengentaskan masalah belajar sebab faktor tersebut merupakan komponen pendidikan yang antara satu dan lainnya saling mempengaruhi serta berkaitan sehingga harus ada dan terpadu.Berikut adalah faktor pendukung sehingga pendekatan remedial dapat mengentaskan masalah belajar peserta didik.

a) Peserta Didik yang Mengalami Masalah Belajar

Peserta didik merupakan individu-individu yang memiliki karakteristik yang berbeda-beda dan menempati posisi sentral dalam penyelenggaraan proses pendidikan dan pembelajaran di Sekolah. Dengan demikian prilaku belajar dan hasil belajar mereka berbeda-beda pula.

Demikian halnya pada SMK Negeri di Kota Parepare, peserta didik juga memiliki karakteristik dan tipe belajar yang berbeda-beda sehingga di antara mereka ada yang cepat mencapai ketuntasan pembelajaran dan ada pula yang lambat.Pengamatan di lapangan menunjukkan bahwa tidak semua peserta didik bebas dari masalah belajar. Dengan demikian maka peserta didik yang mengalami masalah belajar, baik yang disebabkan oleh faktor dalam diri maupun dari luar diri, termasuk belum mencapai standar KKM setelah mengikuti tes hasil belajar memiliki peran yang sangat besar dalam pelaksanaan remedial sebab prilaku peserta didik dalam pembelajaran menentukan efek yang akan dicapai. 
Dalam kenyataan di lapangan, sebagian besar peserta didik telah mempunyai motivasi, minat, dan upaya yang kuat dalam mengikuti remedial. Hal ini antara lain disebabkan karena peserta didik takut tinggal kelas, takut tidak memenuhi syarat ikut praktik pengalaman lapangan, dan takut dropout, sebagaimana diungkapkan salah seorang guru PAI bernama Sakka Ihsan (guru PAI SMKN 2 Parepare) bahwa: "Peserta didik mempunyai motivasi dan upaya yang kuat dalam mengikuti remedial sebab ketuntasan pembelajaran PAI juga menjadi salah satu syarat untuk dapat mengikuti kegiatan Praktik Pengalaman Lapangan (PPK)".

Berdasarkan penelitian dan pengamatan peneliti di lapangan, semua peserta didik SMKN di Kota Parepare yang memiliki masalah belajar, terutama yang belum mencapai standar KKM telah mengikuti remedial. Implementasi pendekatan remedial ini dilaksanakan pada SMKN di Kota Parepare bertujuan mengentaskan masalah belajar yang dialami peserta didik.

a. Kompetensi dan Kinerja Guru Pendidikan Agama Islam

Keberadaan guru PAI yang berkualitas pada lembaga pendidikan formal menurut penulis amat penting dalam rangka mendukung tercapainya kualitas pendidikan dan pembelajaran sebagaimana yang diharapkan. Berdasarkan penelusuran dokumen di lapangan, ditemukan bahwa guru PAI pada SMKN di Kota Parepare seluruhnya telah memenuhi standar kualifikasi pendidikan S-1 dan bahkan beberapa orang di antaranya S2 program studi Pendidikan Agama Islam, sehingga dapat peneliti simpulkan bahwa guru PAI SMKN di Kota Parepare merupakan guru yang kompeten di bidangnya sehingga dapat mendukung keberhasilan pendidikan dan pembelajaran, termasuk pembelajaran remedial. Hal ini sejalan dengan apa yang dikemukakan oleh Muhammad Idris Usman (Pengawas Pendidikan Agama Islam jenjang pendidikan menegah) bahwa faktor-faktor yang mempengaruhi sehingga pendekatan remedial dapat berhasil mengentaskan masalah belajar peserta didik adalah:

1) Antusiasme guru PAI SMKN. Guru PAI SMKN memiliki motivasi dalam melaksanakan proses pembelajaran dengan berprinsip bahwa mengajar selain merupakan kewajiban juga dianggap sebagai sebuah pengabdian (ibadah) kepada Allah swt.

2) Optimalisasi kegiatan ekstra kurikuler bagi pelaksanaan pembelajaran mata pelajaran PAI yang biasa dikenal dengan program Bimbingn IMTAQ.

3) Adanya inisiatif dari guru PAI dengan memberikan bimbingan belajar di luar jam pelajaran, seperti pemberian tugas (resitasi) dan pelaksanaan remedial itu sendiri.

Sejalan dengan pendapat di atas, Sakka Ihsan (guru PAI SMKN 2 Parepare) mengemukakan bahwa faktor yang mempengaruhi keberhasilan remedial di antaranya adalah keterbukaan guru mengenai hasil belajar peserta didi, rasa takut peserta didik jika tidak mencapai standar ketuntasan, sikap tegas guru, adanya ketuntasan nilai mata pelajaran PAI menjadi syarat untuk dapat ikut PPL sehingga peserta didik mengejar nilai yang memenuhi standar ketuntasan, dan mata pelajaran PAI termasuk matapelajaran Ujian Standar Berbasis Nasional (USBN).

Faktor lain yang mendukung keberhasilam pembelajaran remedial sebagaimana yang dikemukakan oleh Muhammad Tang ( guru PAI SMKN 3) yaitu 
1) Kerjasama yang baik antara sesama guru, 2) Pendekatan persuasif kepada peserta didik, 3) Penerapan hukuman yang diikuti dengan pemberian nasihat, 4) Pemberian pemahaman kepada peserta didik baik secara individual maupun secara kelompok tentang maksud dan tujuan pendidikan dan perencanaan masa depan.

Pembelajaran remedial ini sangat bermanfaat dalam rangka mengoptialkan perkembangan peserta didik. Dikatakan bermanfaat sebab peserta didik melewati beberapa tahapan untuk mencapai hasil proses pembelajaran sesuai standar KKM. Di samping itu, pemberian pembelajaran remedial kepada kepada peserta didik sangat positif sekali untuk meningkatkan kualitas pendidikan dan pembelajaran.

b. Dukungan Guru BK

Guru bimbingan dan konseling merupakan ujung tombak dalam penyelenggaraan layanan bimbingan dan konseling di Sekolah, termasuk layanan dalam mengentaskan masalah belajar peserta didik. Sekolah perlu didukung guru BK yang mamadai dan berkualitas sesuai dengan ketentuan sekolah agar visi-misi sekolah dapat terwujud sebagaimana yang diharapkan.

Keberadaan guru BK yang berkualitas menurut penulis amat penting dalam menopang pencapaian tujuan pendidikan dan pembelajaran di Sekolah, termasuk pada SMKN di Kota Parepare. Hasil penelitian di lapangan menunjukkan bahwa semua SMKN di Kota Parepare memiliki lembaga BK yang didukung oleh guru BK yang berkualitan dilihat dari latarbelakang pendidikan dengan kualifikasi pendidikan minimal S-1 program studi bimbingan dan konseling.

Dukungan guru BK dalam implementasi pendekatan remedial pada mata pelajaran PAI sebagaimana dikemukakan oleh Abd. Majid (guru BK SMKN 1 Parepare) bahwa "lembaga BK di sekolah kami mengevaluasi hasil belajar peserta didik setiap semester berdasarkan laporan hasil evaluasi pembelajaran yang telah dilaksanakan oleh guru PAI. Tindak lanjut pemberian layanan kepada peserta didik dilakukan oleh lembaga BK berdasarkan hasil evaluasi". Dengan demikian dapat dipahami bahwa dukungan guru BK sangat berarti dalam rangka mengoptimalkan pencapaian ketuntasan pembelajaran PAI.

Dukungan guru BK dalam mewujudkan ketuntasan pembelajaran PAI tidak terlepas dari dukungan kepala Sekolah.Dukungan kepala sekolah menjadi pemicu yang memunculkan motivasi yang kuat untuk mewujudkan kinerja yang baik dari guru BK. Hal ini sejalan dengan apa yang dikemukakan oleh Pengawas guru PAI Idris Usman bahwa salah satu faktor yang mempengaruhi sehingga remedial dapat mengentaskan masalah belajar peserta didik adalah adanya dukungan kepala Sekolah. Lebih lanjut Beliau menyatakan bahwa"umumnya Kepala SMK di Kota Parepare memberikan dukungan positif terhadap kegiatan remedial yang dilakukan oleh guru PAI". Dengan demikian dapat disimpulkan bahwa kerja sama dan keterpaduan dalam penyelenggaraan pendidikan dan pembelajaran PAI di Sekolah merupakan satu keniscayaan, hal yang sangat urgen untuk mewujudkan mutu pendidikan dan pembelajaran sebagaimana yang diharapkan.

\section{Pembahasan Hasil Penelitian}

Agar lebih terarah dan terfokusnya pembahasan hasil penelitan ini, maka pembahasannya dibagi ke dalam tiga bagian yaitu; (1) Bentuk pelaksanaan remedial mata pelajaran PAI, (2) Dukungan guru Bimbingan dan Konseling terhadap pelaksanaan program remedial pada mata pelajaran PAI, dan (3) Faktor-faktor yang mempengaruhi remedial sehingga dapat mengentaskan masalah belajar PAI peserta didik SMKN di Kota Parepare. 
a. Bentuk Implementasi Pendekatan Remedial Mata Pelajaran PAI,

Pembelajaran adalah inti dari kegiatan pendidikan. Baik buruknya mutu pendidikan (prestasi belajar) sangat ditentukan oleh baik buruknya proses pembelajaran di dalam kelas. Hal ini menjadi tanggungjawab setiap guru sebagai pendidik profesional yang tidak hanya bertugas mengajar tetapi juga bertugas mendidik, membimbing, mengarahkan, melatih, menilai dan mengevaluasi peserta didik, sebagaimana yang diamanahkan dalam Undang-Undang Sistem Pendidikan Nasional.

Realitas di lapangan menunjukkan bahwa belum semua peserta didik mendapatkan layanan pembelajaran sesuai karakteristiknya, dan belum semua peserta didik belajar dengan penuh kesungguhan sehingga di antara mereka ada yang belum mencapai hasil belajar sebagaimana yang telah ditetapkan.

Di sisi lain harapan sekolah adalah semua peserta didik dapat berhasil dan tidak ada yang tinggal kelas. Hal ini sesuai yang diungkapkan oleh salah seorang guru PAI bernama Nurhayati bahwa "harus diusahakan sedapat mungkin tidak ada peserta didik yang tinggal kelas".Hal ini sejalan dengan visi SMKN 3 Parepare yakni unggul dalam prestasi, kompeten pada bidang keahlian berdasarkan IPTEK dan IMTAQ menuju SMK rujukan.

Pembelajaran remedial pada SMKN di Kota Parepare diberikan kepada peserta didik yang mengalami masalah belajar.Seorang peserta didik diduga mengalami masalah belajar jika yang bersangkutan tidak berhasil mencapai taraf kualifikasi hasil belajar tertentu berdasarkan kriteria ketuntasan pembelajaran.Peserta didik yang merasa perlu meningkatkan ketuntasan belajarnya pada topik-topik tertentu juga merupakan sasaran secara umum pembelajaran remedial.Sehingga dapat dikatakan bahwa pembelajaran remedial juga merupakan upaya pengayaan pemahaman peserta didik, bukan hanya pembelajaran bagi anak yang tidak pintar dan tidak mencapai standar KKM. Hal ini sejalan dengan apa yang dikemukakan oleh S. Nasution, sebagaimana pada bab terdahulu bahwa“bagi peserta didik yang masih kurang menguasai bahan pelajaran tes formatif merupakan alat untuk mengungkapkan dimana sebetulnya letak kesulitannya".

Peserta didik SMKN di Kota Parepare yang mengalami masalah berkaitan dengan hasil belajarnya disebabkan oleh berbagai faktor baik yang berasal dari dalam diri maupun dari luar diri mereka. Faktor yang dimaksud adalah sebagaimana yang dikemukakan oleh Hellen yakni yang terdapat di dalam diri peserta didik antara lain: a) Kurangnya kemampuan dasar yang dimiliki oleh peserta didik, b) Kurangnya bakat khusus untuk suatu situasi belajar tertentu. c) Kurangnya motivasi untuk belajar. d) Situasi pribadi terutama emosional yang dihadapi peserta didik pada waktu tertentu. e) Faktor jasmaniah yang tidak mendukung kegiatan belajar seperti gangguan kesehatan, cacat tubuh, gangguan penglihatan, gangguan pendengaran dsb. E) Faktor hereditas (bawaan) yang tidak mendukung kegiatan belajar, seperti buta warna, kidal, trepor, cacat tubuh dan lain sebagainya. Sedanglan faktor yang berasal dari luar diri mereka antara lain situasi di Sekolah, pengaruh teman sebaya, lingkungan social, dan situasi di lingkungan keluarga mereka.

Peserta didik dikatakan gagal apabila yang bersangkutan tidak dapat mengerjakan atau mencapai prestasi yang semestinya dalam pembelajaran PAI. Pada dasarnya setiap orang tidak akan sama persis kemampuannya dalam memahami suatu konsep. Berdasarkan hal ini, sebaiknya pembelajaran remedial dilaksanakan juga secara individual sesuai dengan karakteristik peserta didik yang bersangkutan. 
Pembelajaran remedial dapat menjadi alternative solusi dalam permasalahan kesulitan belajar peserta didik.Pembelajaran remedial dapat memperbaiki prestasi belajar peserta didik sehingga mencapai kriteria ketuntasan yang telah ditetapkan.

Sebagaimana telah dikemukakan pada bagian terdahulu bahwa pendekatan pembelajaran remedial merupakan bentuk pembelajaran yang tidak sekedarmengulang terhadap bahan-bahan pelajaran pokok yang belum dapat dikuasai oleh peserta didik tetapi juga merupakan studi kasus bagi guru untuk mengetahui dan menangani peserta didik yangmengalami masalah belajar.

Bentuk implementasi remedial mata pelajaran PAI pada SMKN di Kota Parepare dapat ditinjau dari tiga perspektif utama, yaitu dilihat dari hasil wawancara dengan para informan dan ditinjau dari hasil observasi serta studi dokumentasi pada saat pelaksanaan penelitian. Pertama, hasil wawancara menggunakan instrumen pedoman wawancara menunjukkan bahwa pendekatan remedial telah diterapkan pada seluruh SMKN di Kota Parepare dalam rangka upaya mengoptimalkan capaian pembelajaran. Peserta didik yang belum mencapai standar KKM diberi layanan remedial hingga yang bersangkutan dapat mencapai standar KKM yang telah ditetapkan, namun bentuk pelaksanaannya masih sangat terbatas dan beragam sesuai dengan situasi, kondisi, kemampuan dan kehendak setiap guru PAI. Guru PAI menerapkan bentuk remedial yang berbeda antara satu dengan yang lainnya.

Terbatasnya bentuk remedial tersebut sebagaimana dapat dilihat pada penuturan para informan yang telah dikemukakan terdahulu yakni ada guru PAI yang memilih bentuk remedial kelompok dan perorangan setelah tes formatif, ada remedial setelah ujian semester akhir, ada remedial klasikal setelah tes sumatif, dan ada yang melaksanakan remedial secara insidentil. Pada umumnya remedial yang dilaksanakan fokus pada pembahasan kembali soal-soal ujian/ulangan yang belum dapat dijawab peserta didik dengan benar kemudian diujikan kembali sampai tuntas atau dituntaskan, dengan tidak mengatasi masalah belajar yang dialami peserta didik dalam proses pembelajaran seperti adanya kebiasaan buruk dalam belajar, kurangnya motivasi dan minat belajar PAI, suka menunda-nunda tugas, sulit menghafal ayat-ayat alQuran, lambat dalam memahami pelajaran, lambat dalam membaca dan sebagainya.

Realitas dalam penelitian ini jika dirujuk pada pendapat Sukmadinata sebagaimana dikutip pada bagian terdahulu yang menyatakan bahwa layanan remedialatau korektif dapat dilakukan melalui konseling individual atau kelompok, juga melalui kegiatankegiatan kelompok atau melalui pengajaran modul. Remedial yang demikian sengaja memperbaiki kelemahan, kesalahan, atau kekurangan peserta didik yang segera dapat ditemukan sendiri oleh peserta didik berdasarkan evaluasi yang diberikan secara kontinu maka remedial yang dilaksanakan pada SMKN di Kota Parepare belum sepenuhnya sesuai dengan tutntutan yang dikehendaki oleh remedial itu sendiri.

Kedua, ditinjau dari hasil observasi menunjukkan bahwa terdapat beberapa aktivitas dan juga strategi pembelajaran yang diterapkan dalam proses belajar pembelajaran remedial. Aktivitas dan strategi pembelajaran yang dimaksud adalah pembelajaran langsung (ceramah), menulis dan mengerjakan ulang soal yang telah diujikan, menghafal surah-surah pendek, tadarrus, sosiodrama, dan belajar terbimbing.

Dominannya pembelajaran langsung dengan menggunakan metode ceramah, mengerjakan soal, menghafal surat-surat pendek, belajar terbimbing yang dianggap sebagai bentuk pembelajaran yang berpusat pada guru memberi gambaran jelas tentang masih perlunya peningkatan kinerja guru. Masih tampak adanya guru yang tidak menfasilitasi belajar dengan 
menciptakan suasana belajar yang kondusif, menggunakan dan mengelola proses dan sumber belajar yang sesuai seperti yang diharapkan dalam istilah perbaikan kinerja menurut Association for Educational Communication and Technology (AECT) yang dikutip oleh Alan \& Molenda yang mengatakan bahwa teknologi pendidikan adalah studi dan proses etis untuk menfasilitasi belajar dan memperbaiki kinerja dengan menciptakan, menggunakan, dan mengelola proses dan sumber teknologi yang sesuai. Meskipun demikian dari sejumlah informan dalam penelitian, terdapat dua orang yang menyatakan bahwa pembelajaran remedial yang dilaksanakan menggunakan strategi dan media yang sesuai dengan karakteristik peserta didik.

Begitu pula dominannya pembelajaran berbasis pada guru karena pembelajaran hanya merujuk pada apa yang disebut oleh Reugeluth dengan istilah konstruksi (construction) yang dilakukan untuk peserta didik sehingga berorientasi pasif dan tidak dirancang menjadi instruction (pembelajaran) yang dilakukan oleh peserta didik (peserta didik sangat aktif). Padahal keduanya perlu diselaraskan agar terjadi proses pembelajaran yang di samping berorientasi construction juga dirancang untuk instruction. Hal ini dibuktikan dengan pernyataan $\mathrm{Hj}$. Nurhayati yang telah dikemukakan pada bagian sebelumnya bahwa metode yang saya gunakan dalam remedial lebih banyak ceramah dan nasihat. Khusus dalam mengatasi ketidakmampuan peserta didik membaca alquran saya gunakan metode iqra', saya hadapi satu persatu peserta didik yang belum bagus bacaan qur'annya.Hal ini membuktikan bahwa bentuk pelayanan masih cenderung berpusat pada guru termasuk memberikan materi pembelajaran dan mengajar langsung membaca al-qur'an.

Ketiga, berdasarkan penelusuran dokumen yang berkaitan dengan pembelajaran remedial pada lokasi penelitian ditemukan adanya perbedaan pada setiap sekolah.Data peserta didik yang telah mengikuti pembelajaran remedial pada SMKN 1 Parepare ditemukan pada guru PAI dan pada ruang BK, sementara pada SMKN 2 dan SMKN 3 Parepare didokumentasikan oleh masingmasing guru PAI.

Berdasar pada uraian di atas, jika didirujuk pada pendapat Abin Syamsuddin Makmun dalam Amin Budiamin sebagaimana telah dikemukakan pada tinjauan pustaka, yang mendefinisikan pembelajaran remedial sebagaiupaya guru untuk menciptakan suatu situasi yang memungkinkan peserta didik atau kelompok peserta didik tertentu lebih mampu mengembangkan dirinya seoptimal mungkin sehingga dapat memenuhi kriteria keberhasilan minimal yang diharapkan, dengan melalui suatu proses interaksi yang terencana, terorganisir, terarah, terkoordinasi, terkontrol dengan lebih memperhatikan taraf kesesuaiannya terhadap keragaman kondisi objektif individu dan atau kelompok peserta didik yang bersangkutan serta daya dukung sarana dan lingkungannya maka dapat disimpulkan bahwa bentu-bentuk implementasi pendekatan remedial yang dilaksanakan pada SMK Negeri di Kota Parepare belum optimal.

\section{b. Dukungan Guru BK terhadap Implementasi Remedial}

Dari sudut pandang BK sebagai profesi bantuan (helping profession) layanan BK harus didukung oleh personil yang memiliki kualitas profesional tinggi sehingga akan dapat memberikan pelayanan profesional yang berkualitas, akurat, dan dapat memberikan hasil yang optimal sesuai dengan kebutuhan dan tuntutan semua pihak yang berkepentingan (stakeholders). 
Optimalisasi sumber daya berkenaan pelaksanaan BK merupakan alternatif yang paling tepat untuk mewujudkan capaian pembelajaran yang optimal.

Bimbingan dan Konseling sebagai suatu organisasi dan bagian yang tak terpisahkan dalam sistem pendidikan di sekola, didesain untuk dapat berkontribusi terhadap upaya peningkatan mutu bagi optimalisasi perkembangan peserta didik.Layanan BK yang dilaksanakan di sekolah oleh guru pembimbing menempati posisi yang strategis dalam upaya perbaikan kualitas hasil belajar peserta didik, maupun upaya optimalisasi perkembangan peserta didik sesuai dengan potensi yang dimilikinya.Meskipun jika ditilik secara seksama dari tinjauan profesional, manajemen BK di sekolah belum berjalan sepenuhnya sesuai yang diharapkan.

Sebagai salah satu upaya peningkatan mutu, BK di sekolah perlu dilaksanakan oleh guru pembimbing profesional, dikelola, dan diberdayakan agar dapat memberikan layanan yang bermutu dan menghasilkan produk atau hasil yang optimal. Kerjasama yang baik antara kepala sekolah, guru BK, dan guru mata pelajaran dalam pelaksanaan pendidikan dan pembelajaran, diharapkan mampu mewujudkan capaian pembelajaran yang bermutu tinggi.

Demikian halnya dalam pembelajaran PAI, sangat dibutuhkan kerjasama yang baik antara guru PAI dengan guru BK. Dukungan guru BK terhadap optimalisasi capaian pendidikan dan pembelajaran, termasuk dalam hal pengentasan masalah belajar yang dapat menghambat perkembangan peserta didik melalui pendekatan remedial amat diperlukan.

Terdapat beberapa dukungan guru BK dalam hubungannya dengan implementasi pembelajaran remedial. Berdasarkan hasil wawancara dean hasil observasi yang telah dikemukakan sebelumnya dapat ditarik lesimpulan bahwa dukungan guru BK terhadap pembelajaran PAI berupa kerjasama dalam hal memberikan layanan konseling bagi peserta didik yang sering tidak hadir mengikuti proses pembelajaran dan yang turun prestasi belajarnya, mendiagnosis kesulitan belajar peserta didik, dan memberikan layanan informasi bagi peserta didik yang harus mengikuti remedial. Dukungan diberikan baik di dalam maupun di luar ruangan memberikan kontribusi dalam mengentaskan masalah belajar peserta didik. Dukungan dan kerjasama yang baik antara guru PAI dan guru BK merupakan cara yang baik dalam mengentaskan masalah belajar peserta didik.

Hal ini sesuai dengan teori yang dikemukakan Nana Syaodih Sukmadinata bahwa bahwa Keseluruhan proses pendidikan terutama pendidikan di sekolah meliputi tiga bidang utama, yaitu bidang: kurikulum dan pembelajaran, manajemen pendidikan, dan bimbingan dan konseling. Salah satu asas yang harus diterapkan dalan BK adalah asas keterpaduan.Asas keterpaduan menuntut agar layanan BK terpadu dengan layanan-layanan sekolah lainnya dan memadukan seluruh aspek dalam pribadi peserta didik.

Jenis aktivitas pembelajaran remedial yang biasa diterapkan dibagi ke dalam dua bagian, yakni aktivitas di dalam dan aktivitas di luar ruangan.Aktivitas di dalam ruangan merupakan aktivitas yang paling banyak digunakan mengiringan setiap pembelajaran berlangsung.

Walaupun berbagai aktivitas pembelajaran seperti dijelaskan di atas dipandang baik dalam pelaksanaan pembelajaran.Namun, beberapa persoalan yang timbul sering menjadi tantangan berat untuk diatasi.Persoalan yang dimaksud adalah kesulitan internal peserta didik seperti pengetahuan dasar yang dimiliki, sikap, dan keterampilan dalam mengikuti pembelajaran yang masih terbatas.

Dalam hubungannya dengan kemampuan yang harus dimiliki oleh peserta didik dalam proses pembelajaran merupakan tujuan yang hendak diwujudkan agar peserta didik dapat 
mencapai hasil yang diinginkan. Kemampuan yang dimaksud adalah seperti yang dijelaskan oleh Bloom dalam tiga kategori, yaitu (1) kognitif, (2) afektif, dan (3) prikomotorik. Kemampuan ini perlu dimiliki peserta didik sebagai hasil dari proses pendidikan dan pembelajaran.

Kedua, kesulitan eksternal yang berhubungan dengan rasio atau perbandingan guru dengan peserta didik dan keterbatasan sumber termasuk sarana dan prasarana belajar. Walaupun jumlah perbandingan guru dan peserta didik di sekolah lain mungkin sudah mendekati ideal 1:20 atau bahkan 1:15, tapi kasus pada SMKN di Kota Parepare rata-rata 1:220, suatu jumlah yang sangat merepotkan. Selain itu, kesulitan sarana dan prasarana menjadi hal yang sangat klasik bukan saja terjadi di sekolah-sekolah yang masih berstandar local, melainkan juga sekolah yang sudah berstandar nasional.

\section{c. Faktor-faktor yang Mempengaruhi sehingga Remedial dapat Mengentaskan Masalah Belajar Peserta Didik}

Besarnya tuntutan peningkatan kualitas dan ketuntasan pembelajaran di satu sisi tidak sebanding dengan realitas hasil belajar peserta didik di sisi lain. Ketuntasan pembelajaran peserta didik ditandai dengan masih adanya peserta didik yang tidak dapat mencapai standar KKM pada setiap pelaksanaan ujian.Hal ini menjadi indikasi bahwa belum semua masalah belajar peserta dapat terentaskan.

Pengentasan masalah belajar peserta didik merupakan satu keniscayaan sebab jika tidak dilakukan dengan baik maka maslah tersebut akan bertambah kronis dan akhirnya peserta didik bisa tinggal kelas atau dropout. Hal ini menjadi tanggungjawab bagi setiap guru mata pelajaran, termasuk guru mata pelajaran PAI pada SMKN di Kota Parepare.

Hasil penelitian di lapangan menunjukkan pengentasan masalah belajar PAI peserta didik pada SMKN di Kota Parepare telah dilakukan dilakukan oleh guru PAI. Masalah belajar yang dialami peserta didik beragam. Hal tersebut sejalan dengan pendapat Moh. Surya dalam Hellen A sebagaimana telah dikemukakan pada tinjauan pustakayang mengemukakan bahwa ada beberapa ciri tingkah laku yang merupakan manifestasi dari gejala kesulitan belajar peserta didik, antara lain: a) Menunjukkan hasil belajar yang rendah (di bawah rata - rata nilai yang dicapai oleh kelompok kelas); b) Hasil yang dicapai tidak seimbang dengan usaha yang dilakukan. Mungkin murid yang selalu berusaha dengan giat tapi nilai yang dicapai selalu rendah; c) Lambat dalam melakukan tugas - tugas kegiatan belajar, ia selalu tertinggal dari kawan - kawannya dalam menyelesaikan tugas sesuai dengan waktu yang tersedia; d) Menunjukkan tingkah laku yang berkelainan, seperti membolos, datang terlambat, tidak mengerjakan pekerjaan rumah, mengganggu di dalam dan di luar kelas, tidak mau mencatat pelajaran dsb; e) Menunjukkan sikap - sikap yang kurang wajar, seperti acuh tak acuh, menentang, berpura - pura, dusta dsb. Hal ini dialami pula oleh beberapa orang peserta didik pada SMKN di Kota Parepare.

Masalah belajar yang dialami peserta didik menurut hemat penulis disebabkan oleh faktor internal dan eksternal, antara lain gangguan secara fisik, kelemahan-kelemahan secara psikis, emosi yang tidak terkontrol, kelemahan yang disebabkan oleh sikap dan kebiasaan yang buruk, dan tidak memiliki ketrampilan-ketrampilan dan pengetahuan dasar yang diperlukan, disamping adanya faktor eksternal, yakni situasi keluarga, sekolah dan masyarakat yang tidak mendukung perkembangan peserta didik. 
Dominannya pelaksanaan remedial yang berpusat pada pembahasan soal-soal yang belum tuntas membuat sebagian peserta didik menjadi cenderung pasif, kreativitas dalam mengatasi kelemahandan kekurangan diri tidak dapat teratasi dengan baik, dan keberagaman kecerdasan belum tergali dengan baik. Sikap sebagian guru cenderung memberikan kepercayaan sepenuhnya kepada peserta didik mempelajarai soal-soal yang mereka belum paham jawabanya secara mandiri tanpa memberikan bantuan dalam membahas ulang secara mendalam kompetensi yang belum tuntas, bahkan terdapat perlakukan peserta didik melalui cara, strategi, dan pendekatan yang sama, seperti dipahami dari hasil wawancara yang telah dikemukakan pada uraian sebelumnya yang memberikan pelajaran sesuai rutinitas sebagai guru mata pelajaran yang selalu berhadapan dengan keragaman watak, sikap, dan tingkah laku peserta didik tetapi tidak pernah memberikan perlakukan yang berbeda terhadap gaya belajar yang berbeda-beda.

Namun demikian secara umum tampak adanya antusiasmeguru PAI SMKN di Kota Parepare dalam mengentaskan masalah belajar peserta didik.Guru PAI SMKN di Kota Parepare memiliki motivasi dalam melaksanakan proses pembelajaran dengan berprinsip bahwa mengajar selain merupakan kewajiban juga dianggap sebagai sebuah pengabdian (ibadah) kepada Allah swt. Hal ini sesuai dengan pengamatan Dr. Muh.Idris Usman selaku pengawas PAI.

Salah satu contoh kasus pada saat paneliti berada dilapangan tiba-tiba ada peserta didik yang kesurupan sehingga dua orang peserta didik lainnya menuju ke ruang guru PAI melaporkan dan memanggil guru PAI menangani hal tersebut. Hal ini merupakan bukti bahwa peserta didik cenderung lebih mempercayakan pengentasan masalah yang mereka alami pada guru PAI dan guru PAI memiliki kepedualian dan sangat antusias membantu peserta didik, bukan hanya pada bidang pembelajaran PAI, namun juga pada bidang lainnya yang sejatinya ditangani oleh guru BK.

Hal lain yang menjadi faktor pendukung sehingga pembelajaran remedial dapat mengentaskan masalah belajar peserta didik adalah optimalisasi kegiatan ekstra kurikuler bagi pelaksanaan pembelajaran mata pelajaran PAI yang biasa dikenal dengan program Bimbingan IMTAQ.Hal tersebut menurut hemat peneliti amat urgen dilakukan untuk lebih mengoptimalkan perkembangan peserta didik.Banyak hal positif yang bisa didapatkan oleh peserta didik melalui kegiatan ekstra kurikuler keagamaan yang tidak didapatkan pada kegiatan intra kulikuler. Terutama yang berkaitan dengan berbagai pengembangan bakat dan cara mengatasi kekurangan seperti keterampilan memimpin persidangan, kemampuan mengemukakan pendapat dalam berdiskusi, mengelola administrasi, kemampuan bacatulis dan menghafal alqur'an, kaligrafi, kedisiplinan dalam beribadah, seni qasidah, kemampuan berceramah, dan sebagainya. Prestasi yang dicapai dalam kegiatan ekstra kurikulum keagamaan sangat menunjang ketuntasan pembelajaran.

Hal lain yang mendukung sehingga remedial dapat mengentaskan masalah belajar peserta didik yang juga merupakan kegiatan ekstra kurikuler sebagaimana yang diungkapkan oleh Pengawas PAI SMK adalah adanya pula inisiatif dari guru PAI memberikan bimbingan belajar di luar jam pelajaran, seperti halnya pemberian tugas (resitasi). Pemberian tugas pekerjaan rumah misalnya menghafal ayat-ayat alQur'an sesuai dengan kondisi dan karakteristik peserta didik dapat membantu mengasah kemampuan peserta didik serta melatih peserta didik memanfaatkan waktu senggang dengan melakukan kegiatan yang positif. 
Hasil wawancara dengan Muh. Tang juga menggambarkan bahwa faktor yang mendukung keberhasilan remedial antara lain adanya kerjasama yang baik antara sesama guru, pendekatan persuasif kepada peserta didik, penerapan hukuman yang diikuti dengan pemberian nasihat, pemberian pemahaman kepada peserta didik baik secara individual maupun secara kelompok tentang maksud dan tujuan pendidikan dan perencanaan masa depan.

Beberapa faktor di atas membuat pelaksanaan remedial dapat mengantarkan peserta didik yang mengalami masalah belajar untuk dapat mencapai skor KBM sebagaimana yang telah ditetapkan pada setiap sekolah.Namun demikian jika apa yang telah laksanakan dalam implementasi remedial pada SMKN di Kota Parepare ini dirujuk pada pendapat Amin Budiamin dan Setiawati sebagaimana telah disampaikan pada bab terdahulu bahwa pembelajaran remedial merupakan salah satu kegiatan utama dari layanan bimbingan belajar serta merupakan rangkaian daripada diagnosis kesulitan belajar peserta didik dan strategi serta teknik pembelajaran dapat dilakukan secara preventif, kuratif, dan pengembangan, maka dapat disimpulkan bahwa pelaksanaan remedial tersebut masih dominan bersifat kuratif sementara cara preventif dan pengembangan masih minim.

Ada beberapa cara yang dapat ditempuh dalam pelaksanaan remedial yaitu :

1) Dilaksanakan pada pertemuan kelas yang terjadwa. Hal ini dilakukan jika sebagian besar warga kelas mengalami kesulitan yang serupa, dengan cara : (a) bahan pelajaran yang belum dipahami dipresentasikan kembali; (b) diadakan latihan/penugasan mengerjakan soal kembali yang bentuknya sejenis dengan soal yang telah diujikan sebelumnya; (c) diadakan pengukuran dan penilaian kembali untuk mendeteksi peningkatan skor hasil belajar ke arah pencapaian KBM.

2) Remedial di luar jam pertemuan regular. Hal ini dilakukan jika yang mengalami kesulitan belajar itu hanya seorang peserta didik atau sejumlah peserta didik tertentu: Dilaksanakan secara face to face pada kelas remedial, yang mengalami kesulitan belajar tertentu, dengan cara : a) peserta didik yang mngalami masalah belajar diberi bimbingan khusus dari guru yang sama atau guru mata pelajaran sampai yang bersangkutan mencapai tingkat penguasaan tertentu untuk kemudian bersama-sama lagi dengan teman-temannya di kelas biasa; 2) dilakukan pengulangan secara total, jika ternyata murid yang bersangkutan prestasinya sangat jauh dari batas ketuntasan belajar minimal yang kita kenal sebagai tinggal kelas.

\section{Simpulan}

Berdasarkan hasil penelitian yang telah dikemukakan padabagian terdahulu maka dapat disimpulkan sebagai berikut:

1. Bentuk-bentuk Pelaksanaan Pendekatan Remedial Mata Pelajaran PAI pada SMKN di Kota Parepare yakni berupa pembelajaran remedial perorangan setelah tes formatif dan kelompok setelah tes sumatif.

2. Dukungan guru Bimbingan dan Konseling terhadap pelaksanaan remedial mata pelajaran PAI bervariasi dan belum optimal. Pada SMKN 1 Parepare dukungan berupa identifikasi dan diagnosis masalah belajar peserta didik, layanan informasi bagi peserta didik yang harus mengikuti remedial, pemberian konseling perorangan terhadap peserta didik yang turun peringkatnya, dan pengawasan terhadap kedisiplinan peserta didik. Sedangkan pada 
SMKN 2 dan SMKN 3 remedial PAI sepenuhnya menjadi tanggungjawab guru PAI tanpa dukungan guru BK.

3. Faktor-faktor yang mempengaruhi remedial sehingga dapat mengentaskan masalah belajar PAI peserta didik adalah antusiasme guru PAI SMKN dalam mengemban tugasnya,optimalisasi kegiatan ekstrakurikuler dengan program Bimbingan IMTAQ, dukungan dari pimpinan (KepalaSekolah) serta adanya inisiatif dari guru PAI memberikan bimbingan belajar di luar jam pelajaran.

DAFTAR PUSTAKA

Ali, Muhammad, dkk., 2008, Psikologi Remaja, Perkembangan Peserta Didik, Jakarta: Bimi Aksara.

Arifin, 2008, Ilmu Pendidikan Islam Tinjauan Teoritis dan Peraktis Berdasarkan Pendekatan Interdispliner, Jakarta: PT. Bumi Aksara.

Asmani, Jamal Ma'mur, 2010, Panduan Efektif Bimbingan dan Konseling di Sekolah, DIVA Press: Jakarta.

Asrohah, Hanun, Sejarah Pendidikan Islam, Jakarta: PT. Logos Wacana Ilmu.

Batubara, Muhyi, 2004 Sosilogi Pendidikan, Jakarta: Ciputat Press.

Budiamin, Amin, Setiawati, 2009, Bimbingan Konseling, cetakan pertama, Jakarta: Direktorat Jendral Pendidikan Islam Departemen Agama RI.

Departemen Pendidikan Nasional, UU No. 20 Tahun 2003, tentang Sistem Pendidikan Nasional (Bandung: Citra Umbara, 2003).

-, 2003, Undang-Undang No. 20 Tahun 2003, Tentang Sistem Pendidikan Nasional. , 2005, Undang-Undang nomor 14 Tahun 2005 tentang Guru dan Dosen.

Fred N, Kerlinger., 2002, Asas-Asas Penelitian Behavioral, Yogyakarta: Gadjah Mada University Press.

Gunarsa, Singgih D., 1987, Dasar dan Teori Perkembangan Anak, Jakarta: PT. BPK. Gunung Muliaa

Hallen A, 2002, Bimbingan dan Konseling, Cet. I, Jakarta: Ciputat Pers.

Matthew, Hergenhahn, H. Olson,2009,Theories of Learning (TeoriBelajar), dialihbahasakanoleh Tri Wibowo B.S., Edisiketujuh, Jakarta: KencanaPrenada Media Group.

Mukhtar dan Widodo Suparto, 2003, Manajemen Berbasis Sekolah, Jakarta: CV. Fifamas. 
Nasution, S., 2011, Berbagai Pendekatan dalam Proses Belajar\&Mengajar, Cet. Ke-15, Jakarta: PT. Bumi Aksara.

Nata, Abudin, 2005. Pendidikan Islam di Era Global (Pendidikan Multikutural, Pendidikan Multi Iman, Pendidikan Agama Moral dan Etika), Jakarta: UIN Jakarta Press.

Natawijaya, Rachman, 1998, Peranan Guru Bimbingan dan Konseling, Bandung: Abardin.

Nizar, Samsul, 2001 Dasar-Dasar Pemikiran Pendidikan Islam, Jakarta: Gaya Media Pratama.

Nurhisan, Juntika, 2003, Dasar-dasar Bimbingan dan Konseling, Bandung: Mutiara.

Nurihsan, Juntika \& Akur Sudianto, 2005, Manajemen Bimbingan dan Konseling di sekolah Dasar Kurikulum 2004, Jakarta: Gramedia Widiasarana Indonesia.

Pathurrohman, Pupuh, 2014, Urgensi Bimbingan dan Konseling di PerguruanTinggi Merajut Asa Fungsi Dimensi Dosen sebagai Konselor, Bandung: PT. Refika Aditama, Cetakan kesatu.

Prayitno, dkk., 1999, Dasar-dasar Bimbingan dan Konseling, Jakarta: Rineka Cipta.

Putra Daulay, Haidar, 2007, Sejarah Pertumbuhan dan Pembaharuan Pendidikan Islam di Indonesia, Jakarta: Kencana

Rahim, Husni, 2005, Madarasah dalam Politik Pendidikan di Indonesia, (Jakaarta: PT. Logos Wacana Ilmu

Ridwan, 2004, Penanganan Efektif Bimbingan dan Konseling di Sekolah, Yogyakarta: Pustaka Pelajar.

Robert. K, Yin., 2003, Case Study Research, Design and Methods, Third Edition, London and New Delhi: Sage Publications.

Sagala, Syaiful, 2010, Konsep dan Makna Pembelajaran untuk Membantu Memecahkan Problematika Belajar dan Mengajar, Cetakan ke- 8, Bandung, Alfabeta.

Singarimbun, Masri, Sofyan Efendi, 1989, Metode Penelitian Survai, Jakarta: LP 3 ES.

Slameto, 2003, BelajardanFaktor-faktor yang Mempengaruhinya, Cet. IV, Jakarta: PT. RinekaCipta.

Sudjana, 2000, Metoda Statistika, Edisi ke-6, Bandung: Tarsito.

Sugiyono, 2012, Metode Penelitian Pendidikan Pendekatan Kuantitatif, Kualitatif, dan R\&D, Cet. Ke-15, Bandung: Alfabeta. 
-, 2005, MemahamiPenelitianKualitatif, Bandung: CV. Alfabeta.

, 2012, MetodePenelitianPendidikanPendekatanKuantitatif, Kualitatif, dan R\&D, Cet. Ke-15, Bandung: CV. Alfabeta.

Sukmadinata, Nana Syaodih, 2007, Bimbingan dan Konseling dalam Praktik, Mengembangkan Potensi dan Kepribadian Siswa, Cetakan pertama, Bandung:Maestro.

Steenbrink, Karel A., Pesantren, Madrasah dan Sekolah; Pendidikan Islam dalam Kurun Modern, Jakarta: LP3ES, 1986..

Tohari, Musnamar, 1992, Dasar-dasar Konseptual Bimbingan dan Konseling Islami, Yogyakarta: VII Press. 
Best, John W. Research in Education, Third Edition. New Jersey: Prentice Hall, 1977.

Corneliun, Eko. Artikel: IndeksPembangunanManusia Indonesia MerosotDrastis. Jakarta: Media Indonesia.com. 3 Nopember 2011.

Damopolii, Muljono. Pesantren Modern IMMIM PencetakMuslim Modern. Cet. I; Jakarta: PT. RajaGrafindoPersada, 2011.

Danin, Sudarwan. Profesionalisasi dan EtikaProfesiGuru, Tilikan Indonesia dan Mancanegara, Bandung: Alfabeta, 2010.

Daradjat, Zakiah, dkk. Ilmu Pendidikan Islam. Jakarta: Bumi Aksara, 2008.

Darmawan, Deni. Teknologi Pembelajaran. Cet. I, Bandung: PT. Remaja Rosdakarya, 2011.

Daud,Afrianto.Agar Madrasah Tak Jadi Anak Tiri, http://afriantodaud.blogspot.com. 24 Januari 2008.

Degeng, NyomanSudana dan YusufhadiMiarso. Buku Pegangan Teknologi Pendidikan: Terapan Teori Kognitif dalam Desain Pembelajaran. Jakarta: Departemen Pendidikan dan Kebudayaan, 1993.

Departemen Pendidikan dan Kebudayaan. Kamus Besar Bahasa Indonesia. Cet.III; Jakarta: Balai Pustaka, 1990

Dhofier, Zamakhsyari. Lembaga Pendidikan Islam dalam Perspektif Nasional dalam Prisma, Edisi 9 September 1983.

Dryden, Gordon \& Jeannette Vos, Revolusi Cara Belajar (The Learning Revolution), (SelandiaBaru: The Learning Web, 1999), penerjemah: Word + translation Service. Cet. V, 2002.

Eggen, Paul, Don Kauchak, Educational Psychology, Windows on Classrooms, Third Edition, Columbus, Ohio: Merrill, an imprint of Prentice Hall, Upper Saddle River, New Jersey. 1997. 
Fadjar, A. Malik, Madrasah danTantanganModernitas. Bandung: Mizan, 1999.

NasutiondalamFadli, "Desain Model Pembelajaran Virtual padaPelajaranMatematika", fadlibae.wordpress.com/2011/12/04/desai, (30 Desember 2012).

Faisal, Sanapiah. Format-format PenelitianSosial. Cet. IV; Jakarta: RajaGrafindoPersada, 1999.

Faozi, Zen AR, "MempersoalkanEksistensi Madrasah," dalamCkairulFuad Yusuf dkk, Potret Madrasah dalam Media Massa. Cet. Ke-1, Puslitbang Pendidikan Agama dan Keagamaan Badan Litbang dan Diklat Departemen Agama, 2006.

Freire, Paulo, Ivan Illich, Erich Fromm dkk. Menggugat Pendidikan: Fundamentalis Konservatif Liberal Anarkis. Cet. VII, Yogyakarta: Pustaka Pelajar, 2009.

Getteng, Abd. Rahman, Pendidikan Islam di Sulawesi Selatan (Tinjauan Historis dari Tradisional hingga modern), Cet. I; Yogyakarta: Grha Guru, 2005.

Hayat, Bahrul. Menegakkan PilarPendidikan, Ikhlas Beramal Media Informasi Departemen Agama, No. 56 Th. XIII April 2009.

Isjoni, et al.PembelajaranTerkiniPerpaduan Indonesia-Malaysia. Cet. II, Yogyakarta: PustakaPelajar, 2007.

Joice, B. dan Weil, M., Models of Teaching. New Jersey: Prentice-Hall, Inc. 1986

Kasdi, S. dan Nur M. Pengajaran Langsung. Surabaya: University Press, 2000. Majid, Abdul. PerencanaanPembelajaran. Bandung: RemajaRosdakarya, 2008.

Matthew, Hergenhahn, H. Olson, Theories of Learning (TeoriBelajar), dialihbahasakanoleh Tri Wibowo B.S., Edisiketujuh, Jakarta: KencanaPrenada Media Group, 2009.

Mayer, Richard E. Multimedia Learning, Prinsip-prinsipdanAplikasi, Cambridge University Press, 2001.Penerjemah: TeguhWahyuUtomo. Yogyakarta, PustakaPelajar, 2009.

Muijs, Daniel, and David Reynolds, Effective Teaching; Evidence and Practice (TeoridanAplikasi), Edisikedua, Penerjemah: HellyPrajitnoSoetjiptodan Sri MulyantiniSoetjipto, Yogyakarta: PustakaPelajar, 2008.

Mukhtar dan WidodoSuparto. ManajemenBerbasisSekolah. Jakarta: CV. Fifamas, 2003.

Mulkhan, Abdul Munir. Nalar Spiritual Pendidikan Solusi Problem Filosofis Pendidikan Islam. Yogyakarta: PT. Tiara Wacana Yogya, 2002.

Munir, Kurikulum Berbasis Teknologi Informasi dan Komunikasi, Cetakan kedua Bandung: CV. Alfabeta, 2010.

Nasutian, Harun dkk., Tradisi Baru Penelitian Agama Islam, Tinjauan Antardisiplin Ilmu. Cet. 1; Bandung: KerjasamaPusjarlit dengan Penerbit Nuansa, 1998.

Nata, Abudin. Pendidikan Islam di Era Global (Pendidikan Multikutural, Pendidikan Multi Iman, Pendidikan Agama Moral dan Etika). Jakarta: UIN Jakarta Press, 2005.

-----. Perspektif Islam Tentang Strategi Pembelajaran. Jakarta: Kencana, 2009.

Putra Daulay, Haidar, Dinamika Pendidikan Islam di Asia Tenggara, Jakarta: PT. Rineka Cipta, 2009. 